Gut, 1969, 10, 921-923

\title{
Transmural electrical potential difference of the human colon
}

\author{
MICHAEL G. GEALL, ROBERT J. SPENCER, AND SIDNEY F. PHILLIPS \\ From the Mayo Graduate School of Medicine, University of Minnesota, and the Section of \\ Proctology and the Gastroenterology Unit, Mayo Clinic and Mayo Foundation, \\ Rochester, USA
}

SUMMARY The electrical potential across the human colon was measured by a technique which accurately reflects the true mucosa-to-serosa potential difference. Large negative mucosal potentials were recorded from all regions. The potential difference of the sigmoid colon was significantly greater than that of the rectum. The technique may have important applications to the further study of normal or abnormal colonic function.

The existence of an electrical potential across biological membranes reflects a fundamental property of the membrane to maintain separation of charged particles. In the intestine, negative mucosal electrical potentials have been attributed to the active transport of sodium (Schultz and Zalusky, 1964); moreover, a definition of active transport for any charged particle requires measurement of both the electrical and chemical gradients across the mucosa (Rosenberg, 1948). In the rat (Curran and Schwartz, 1960), dog (Cooperstein and Brockman, 1959), tortoise (Baillien and Schoffeniels, 1961), toad and guinea pig (Ussing and Andersen, 1956), and bullfrog (Cooperstein and Hogben, 1959), colonic mucosal potentials have been related to the transport of sodium. Although the human colon absorbs sodium against large gradients of concentration (Devroede and Phillips, 1969), measurements of the electrical potential of the human colon have been reported in only two subjects (Soergel, Whalen, Geenen, and Gustke, 1966).

In this study, electrical potentials were recorded from the human rectum, sigmoid colon, and proximal colon in healthy subjects. A large, reproducible, negative mucosal potential was measured and significant differences were found between the rectum and the sigmoid colon.

\section{MATERIAL AND METHODS}

The details of the method (Geall, McIlrath, Phillips, Code, and Summerskill, 1968) of recording will be published later (Geall, Code, McIlrath, and Summer- skill. Briefly, potentials between the mucosal surface of the colon and the peripheral blood were measured; preliminary studies established that the peripheral blood is equivalent to the intestinal serosa as a site for a reference electrode (Geall et al, 1968). Electrolyte bridges of saturated potassium chloride $(\mathrm{KCl})$ or $\mathrm{KCl}$ in agar were used, after gas sterilization of the polyethylene tubes (inside diameter $0.12 \mathrm{~cm}$ ) containing the $\mathrm{KCl}$. One electrode was placed in contact with the mucosa and the other was introduced into an antecubital vein through a large-bore needle which was then removed. The electrodes were connected to nonpolarizable calomel half-cells. ${ }^{1}$ A $p \mathrm{H}$ meter $^{2}$ with high internal resistance was used as a direct-current millivoltmeter. In some studies, continuous recordings of potentials were made on a direct-writing instrument. ${ }^{3}$ Thirty minutes of recording were analysed by planimetry to determine the mean potential. The half-cells, voltmeter, and recorder were checked and calibrated before and after each study. All electrical wiring was of the shielded type; the bed and all apparatus had rubber insulation.

Potentials of the lower sigmoid and rectum were measured in eight patients undergoing sigmoidoscopy as a part of a general examination; the endoscopic appearances were normal and there was no history of colonic disease. The recording electrode was placed on the muccs $a$ under direct vision. Measurements were also made on seven healthy volunteers undergoing peroral intubation of the proximal colon for other purposes. The electrode was incorporated in a multilumen transintestinal tube and its position was verified fluoroscopically.

\footnotetext{
'Beckman fiber junction, Beckman Instruments, Fullerton, Calif. ${ }^{2}$ Beckman Expandomatic.

${ }^{3}$ Honeywell Visicorder, Model 1508, Honeywell, Inc, Test Instruments Division, Denver, Col.
} 


\section{RESULTS}

SIGMOID COLON AND RECTUM Potentials recorded 25 and $15 \mathrm{~cm}$ from the dentate line were compared in eight subjects by the Wilcoxon rank sum test (Wilcoxon and Wilcox, 1964). In all measurements, the mucosa was negative relative to the peripheral blood (serosa). The mean ( \pm SE) potential of the sigmoid colon, $28.1 \pm 1.6 \mathrm{mv}$, was significantly greater $(\mathrm{P}<0.001)$ than that of the rectum, 16.1 \pm $1.2 \mathrm{mv}$.

PROXIMAL COLON Potentials ranged from 16.5 to $48.5 \mathrm{mv}$ (mucosa negative) (Table). Although greater potentials were recorded from the ascending and transverse colon than from the other regions, the numbers are insufficient for statistical comparison.

TABLE

TRANSMURAL POTENTIAL DIFFERENCES OF HUMAN COLON Site

Mean

$(m v, \text { mucosa negative })^{1}$

Caecum

Caecum

Ascending colon

Ascending colon

Transverse colon

Descending colon

$16 \cdot 5$

$15 \cdot 3$

$30 \cdot 7$

$31 \cdot 6$

$48 \cdot 5$

$31 \cdot 9$

$26 \cdot 9$

1Obtained by planimetry of 30 minutes of continuous recording; each value represents one subject.

\section{DISCUSSION}

These results demonstrate clearly that a large and reproducible negative electrical potential exists across the wall of the human colon. This potential is greater than that of the human jejunum (Soergel et al, 1966; Schmid, Phillips, and Summerskill, 1969), perhaps reflecting the greater capacity of the colon for absorption of sodium against concentration gradients (Devroede and Phillips, 1969). In addition, a difference was found between the potentials in the rectum and in the sigmoid colon, possibly associated with a decreased permeability and absorptive capacity of the rectal mucosa for sodium (Devroede and Phillips, unpublished observations). These findings agree with previous measurements in two human subjects (Soergel et al, 1966) and are similar to measurements in the rat, dog, tortoise, toad, guinea pig, and bullfrog: 7,10 to 40,20 to $50,28,10$, and $45 \mathrm{mv}$, respectively (Curran and Schwartz, 1960; Cooperstein and Brockman, 1959; Baillien and Schoffeniels, 1961; Ussing and Andersen, 1956; Cooperstein and Hogben, 1959).

The exact origin of mucosal potentials across absorptive epithelium is uncertain. Schultz and
Curran (1968) stressed the relevance of numerous factors, including active transport of anions and cations, concentration differences of ions, and differential permeability of ions across both the mucosal and serosal surfaces of epithelial cells. However, under in-vitro conditions, short-circuit current or potential difference is equalled by active transport of sodium which is thought to be the major causative factor (Schultz and Zalusky, 1964; Clarkson, Cross, and Toole, 1961). In the colon, secretion of bicarbonate against electrochemical gradients (Devroede and Phillips, 1969) may augment a negative mucosal potential due to sodium absorption.

The measurement of colonic potential difference by a relatively simple and reproducible technique offers a new approach to the study of large bowel function in health and in disease states. Future studies of ionic transport by the colon should include measurements of potential for their adequate interpretation. Moreover, certain diarrhoeal diseases associated with disorders of colonic absorption may be further elucidated by electrical studies.

This investigation was supported in part by research grant AM-6908 from the National Institutes of Health, Public Health Service.

\section{REFERENCES}

Baillien, M., and Schoffeniels, E. (1961). Origene des potentiels bioélectriques de l'épithélium intestinal de la tortue grecque. Biochim. biophys. Acta (Amst.), 53, 537-548.

Clarkson, T. W., Cross, A. C., and Toole, S. R. (1961). Electrical potentials across isolated small intestine of the rat. Amer. $J$. Physiol., 200, 1233-1235.

Cooperstein, I. L., and Brockman, S. K. (1959). The electrical potential difference generated by the large intestine: its relation to electrolyte and water transfer. J. clin. Invest., 38, 435-442.

- , and Hogben, C. A. M. (1959). Ionic transfer across the isolated frog large intestine. J. gen. Physiol., 42, 461-473.

Curran, P. F., and Schwartz, G. F. (1960). Na, Cl, and water transport by rat colon. Ibit, $43,555-571$.

Devroede, G. J., and Phillips, S. F. (1969). Conservation of sodium, chloride, and water by the human colon. Gastroenterology, 56, 101-109.

Unpublished observations.

Geali, M. G., Code, C. F., McIlrath, D. C., and Summerskill, W. H. J. (1969), Measurement of gastrointestinal transmural electric potential difference in man. Gut. To be published.

- - McIlrath, D. C., Phillips, S. F., Code, C. F., and Summerskill, W. H. J. (1968). Measurement of the transmucosal potential difference of stomach in unanesthetized man. (Abstr.) Gastroenterology, 54, 1235.

Rosenberg, T. (1948). On accumulation and active transport in biological systems. I. Thermodynamic considerations. Acta chem. scand., 2, 14-33.

Schmid, W. C., Phillips, S. F., and Summerskill, W. H. J. (1969). Jejunal secretion of electrolytes and water in nontropical sprue. J. Lab. clin. Med., 73, 772-783.

Schultz, S. G., and Curran, P. F. (1968). In Handbook of Physiology: Section 6: Alimentary Canal, edited by C. F. Code and W. Heidel, Vol. 3: Intestinal Absorption, pp. 1245-1275. American Physiological Society, Washington, DC.

- , and Zalusky, R. (1964). Ion transport in the isolated 1abbit 
ileum. I. Short-circuit current and $\mathrm{Na}$ fluxes. J. gen. Physiol., 47, 567-584.

Soergel, K. H., Whalen, G. E., Geenen, J. E., and Gustke, R. F. (1966). Potential difference of the intact human intestine during active and passive transport. (Abstr.) J. Lab. clin. Med., 68, 1018.
Ussing, H. H., and Andersen, B. (1956). In Proceedings of the Third International Congress of Biochemistry, Brussels, 1955, pp. 434-440. Academic Press, New York.

Wilcoxon, F., and Wilcox, R. A. (1964). Some Rapid Approximate Statistical Procedures. Lederle Laboratories, New York. 